\title{
PROSE-WRITER'S POETRY: A CORRELATION BETWEEN D. LESSING'S EARLY POETIC WORK AND LATE PERIOD NOVELS
}

\author{
Nataliia Proskurina \\ Lecturer at the Department of History of Foreign Literature and Classical Philology, \\ V.N. Karazin Kharkiv National University, Ukraine \\ e-mail: natatheclassic@gmail.com,orcid.org/0000-0002-9265-6618
}

\section{Summary}

The article is devoted to the study of the poetic work of D. Lessing, the Nobel laureate, better known for her prose. There is a small amount of research on this topic in foreign literary criticism. Such scholars as N. Bentley, C. Murray assess the author's poetic work in close connection with her programmatic feminist novels 'Golden Diary', 'Martha Quest'. Nevertheless, the issue of her early poetry and novels of the late period reveals common features and are promising for study, which determines the relevance of this article. The theme of creative nostalgia, longing for the lost home, exile, feeling of rootlessness is transparent for D. Lessing's work and are present in many of her creations. The writer, experiencing 'the trauma of migration' somehow tries to recur in her works to the location of Africa, a long-forbidden territory for her. Such a creative 'return' for D. Lessing is a way of reconstructing memories, analyzing them, and comparing the past and the present. The author thematizes the problems of collective sin and guilt atonement as a way of self-reinterpretation both in her poetry and prose.

Keywords: D. Lessing, initiation, nostalgia, novel, poetry.

DOI https://doi.org/10.23856/4105

\section{Introduction}

A literary analysis of D. Lessing's creative heritage testifies the writer's preference for the prose form. Her poetic works are considered to be much inferior to prose in the matter of volume and are almost completely unknown to the general public. D. Lessing's oeuvre comprehends about seventy prose works of various literary genres: novels, collections of short stories, journalism, autobiographical works. Nevertheless, the phrasing of the Nobel Committee does not limit her merits exclusively to prose: 'That epicist of the female experience, who with skepticism, fire and visionary power has subjected a divided civilization to scrutiny' (Nobel Committee, 2007). Thus, D. Lessing's poetic work is fewer than prose: two collections of her poems 'The fourteen poems' (1959) and the anthology 'The Wolf People', co-authored with R. Twigger and T. Benson (2002), are known.

The aim of the study is an analysis of two poems from the poetry collection 'The fourteen poems' (1959) and their correlation with the late novels 'Mara and Dann' (1999), 'The Story of General Dann, Mara's Daughter, Griot and Snow Dog' (2005) for finding a deep motive connection between D. Lessing's poetry and prose.

To pursue the given aim it is necessary to fulfill such task as:

1. Analyze modern research on D. Lessing's poetic works.

2. Define the concept of 'nostalgia' in the writer's heritage.

3. Exemplify the perception of Biblical 'sin' and 'guilt' and its representation in text. 
The methodology of the study requires applying an integrated approach based on the synthesis of such methods as mythocritical and structural-semiotic, biographical, comparativehistorical.

\section{D. Lessing-poet as a subject of study for researchers}

D. Lessing's poetry, compared to novels, has become the subject of attention of a few foreign scholars (Nick Bentley, Christine Murray, Robin Graham). Researchers of D. Lessing's poetry point out at common with prose problems thematization, important for all her work. In particular, the collection 'The fourteen poems', written in the period 1940-1950, according to the British literary critic N. Bentley, is an experiment with various forms of "literary selfexpression", and is a kind of reaction of the author to the disappointment in the ability of traditional realistic the novel to convey a sense of fragmentation and disconnection of the modern world" (Bentley, 2015).

The American researcher S. Watkins mentions the poetry of this period is characterized by "critical and creative nostalgia" for the post-colonial past of Southern Rhodesia, the small homeland of D. Lessing (Watkins, 2010). N. Bentley applies the term "trauma of migration" to depict the lyrical hero's longing and to reproduce the feeling of his "alienation" to the new space, the impossibility of returning to the dream homeland.

British scientist D. Walder concludes that after moving to Britain from the periphery D. Lessing experiences a sense of detachment, rootlessness, and estrangement, which is embodied by reevaluating herself through several figurative constructions (Walder, 2008: 113). The researcher puts into action the term "postcolonial nostalgia", which is interpreted as a kind of representation of the writer for her identification with the past. D. Walder emphasizes the need to read the poetic and prose works of D. Lessing through the prism of the postcolonial present.

Ukrainian researcher L. Miroshnychenko, while studying the author's prose, hypothesizes that nostalgia has become a way of expressing D. Lessing's assessments of the past as a "generalized record" and alternative modeling of history as "the past that became part of someone's life' (Miroshnychenko, 2012: 179).

\section{Creative nostalgia in 'Fable'}

The poem 'Fable', first published in 1949, included in the collection 'The fourteen poems', according to N. Bentley, can be considered a nostalgic poem. The literary critic suggests that the collection of poems creates a lyrical hero who resides in the northern hemisphere, but often nostalgically looks back to the south, which is associated with warmth and infinite space". According to N. Bentley, the creative nostalgia that is "embedded" in poetic form indicates that $\mathrm{D}$. Lessing is trying to find ways of self-expression, both in poetry and in a wider discourse (Bentley, 2015).

The first line of the poem begins with the person pronouns 'I' and 'We': 'When I look back I seem to remember singing' / Yet it was always silent in that long warm room./ Impenetrable, those walls, we thought'). ${ }^{1}$

The lyrical hero returns to the world of her childhood. This warm, quiet room is a refuge from the indifferent dark world outside. The feeling of complete security is inspired by the

${ }^{1}$ Christine Murray. 'Fable' and 'Oh Cherry Trees You are Too White For My Heart' by Doris Lessing . Available at: https:// poethead.wordpress.com/ author/ poethead 
repetition of "soothing" adjectives warm, quiet, silent, reminiscing a lullaby. However, children for the present, innocent girls who have yet to go through the stage of adulthood, play in a protected space: 'Dark with ancient shields. The light,/ Shone on the head of a girl or young limbs, / Spread carelessly. And the low voices, / Rose in the silence and were lost as in water,/ Yet, for all it was quiet and warm as a hand.'

This palace of memory that stands in the coasts of the night, nonetheless, is not completely isolated: 'If one of us drew the curtains,/ A threaded rain blew carelessly outside./ Sometimes a wind crept, swaying the flames,/ And set shadows crouching on the walls, / Or a wolf howled in the wide night outside.

The outside world ever and again "breaks" through the veil, slowly destroying this palace of memory, washing away and mixing memories:: 'It might have gone on, dream-like, for ever./ But between one year and the next - a new wind blew?/ The rain rotted the walls at last? Wolves'snouts came thrusting at the fallen beams?/ It is so long ago.'

The space of the night, which exists outside the warm room, is a world dominated by men, and the lyrical heroine tries so fervently to hide from in her memories. The walls, which previously seemed eternal and impenetrable, have disappeared, leaving her defenseless against the universe.

The mimetic picture which arises in the imagination of the heroine is created by means of reception of a ring - at the beginning and the end of poetry the identical scheme "to remember singing" is used: "When I look back I seem to remember singing./ But sometimes I remember the curtained room,/ And hear the far-off youthful voices singing.'

The pause that occurs before these lines is a doubt in the authenticity of memory as a concept. Feelings of security and innocence are unreliable, flickering, resembling a ghost. Memories seem to be "supplemented" by the imagination, blending into a single inseparable total. It's impossible to find the limit of this combination: only the contrasts of the binary oppositions darkness - light/beams, singing - silence, indicate the existence of two worlds.

D. Lessing thematizes the process of growing up ('coming of age') also in the novels from the early works of 'Martha Quest' and 'Grass is singing', in which she depicts the life of female characters, describing the obstacles and prejudices encountered by them, to late novels on their way to "self', to the later novels 'Mara and Dann', 'The Story of General Dann, the daughter of Mara, Griot and the Snow Dog'. According to D. Walder, the novel 'Mara and Dann', is an example of nostalgia for the future, where Africa becomes the center of the world and the cradle of new life (Walder, 2008: 104).

\section{Concept of sin in 'Oh Cherry trees you are too white for my heart'}

The motive of atonement for sin is actualized in both D. Lessing's poetry and prose. The free-verse poem 'Oh Cherry trees you are too white for my heart' is repleted with biblical symbolism. In the Christian tradition, the symbolic image of cherry is sometimes used instead of an apple, the fruit of the tree of knowledge. In painting, the image of the Madonna and Cherry is depicted in paintings by Titian, Dutch artists Joos van Cleve and Dieric Bouts, Flemish artist Quentin Matsys and others. It's obligatory to allude to The Cherry Carol, a song of the Virgin Mary's journey to Bethlehem. At her request, the cherry trees bend down to give her fruit, which correlates with the third line of the poem: 'And all your boughs go dipping towards the river'.

Notwithstanding in the biblical tradition the dipping branches represent the life-giving origin, in D. Lessing's poetry the Christian semantics is transformed: the tree blooms, but does not bear fruit, it "bends" to the ground. The young tree slowly dies, falling out of the cycle of rebirth and death. The world tree, the center of the universe, is declining, it is "oppressed" by guilt for the sins 
of mankind. It mourns with white petals that are too pure and innocent for this world. The personal experience of collective guilt is reflected in the lines: 'And every drop is falling from my heart'.

Anaphoric lexical and syntactic constructions found in the first lines of poetry - ' $\underline{\text { And }}$ all the ground is whitened with your dying,/ And every drop is falling from my hear, / And all your boughs go dipping towards the river' are used to create the effect of injecting a picture of sacrifice. The obvious presence of the author is replaced, according to M.M Bakhtin, "by creative dissolution in the external sound and internal pictorial and rhythmic form" (Bakhtin, 1979: 113). The author "delegates" his powers to the lyrical hero, who is literally dissolved in the landscape.

In the writer's poetry, the lyrical hero turns to higher powers to atone for his guilt and asks for justice from a bearded angel who will stop arbitrariness and stretch the saving twig of a cherry. Yet, in the following lines 'The bearded angel, four-square and straight like a goat, / Lifts a ruminant head and slowly chews at the snow'angel "turns" into a goat, in fact equating to Azazel, a fallen angel, a demon of the desert, who rebelled against the will of the Almighty. According to Biblical text, a "scapegoat" is sacrificed to Azazel. Sacrificial animal is supposed to symbolically take all the sins of mankind and die in the wilderness: "And Aaron shall cast lots upon the two goats; one lot for the Lord, and the other lot for the scapegoat" (Bible, King James Version).

The artistic world of D. Lessing's prose is also saturated with biblical symbolism: the fate of the main characters of the dilogy is a reflection of an ancient ritual: the symbolic laying of sin on two sacrificial animals. Nonetheless, Mara and Dann's wandering through the desert of Ifrik doesn't bring them an expected death, the characters are imprisoned in a confined space. No angel will give a saving hand. Travel journey correlates with the mythological motif of the road, the return to the lost Paradise. In the text of the dilogy, there is a biblical motif of the journey, the search for the "Holy Land", which Mara and Dann are obliged to lead. However, their "flock" refuses to follow their "rescuers", so the sister and brother are forced to pull on ritual clothes alone and go on, hoping for salvation, like obedient dumb animals.

The image of the sacrificial goat in D. Lessing's poems correspond to the fine arts. In particular, the well-known painting of the English Pre-Raphaelite William Holman Hunt 'The Scapegoat' (1854-1856). In the foreground of the picture, one sees a scapegoat in a desert land that has turned white with salt. In the background, the skeletons of dead animals are depicted in detail. R. L Stein studied the poetics of the Pre-Raphaelites and noted their 'desire to materialize the ideal, fictional worlds and make them visually convincing' (Stein, 1975: 124).

Hunt's painting is distinguished by attention to the smallest details, their almost photographic realism. Due to such detailing, the viewer is not presented with an abstract embodiment of sin, but with an unfortunate creature who is doomed to die. The imminent death of an animal becomes apparent due to physical signs.

While W. Hunt carefully draws the figure of a sacrificial goat (from a red sacrificial wreath on the horns to a tongue protruding from thirst), D. Lessing simply depicts a ritual animal of the Old Testament, which has long since become a metaphor. Unlike Pre-Raphaelite aesthetics in its pursuit of a detailed reflection of the physical world, D. Lessing prefers a metaphysical reproduction of the sin concept. The writer deliberately avoids excessive detail, both in poetic and prose texts. The portrait characteristics of the characters are often fleeting, focusing on one characteristic feature: 'She could see herself, so thin, only bones with skin stretched over them. Her eyes were deep in her face'(Lessing, 2009).

The author's skepticism in poetry finds its expression in a special syntax, filling it with interrogative sentences that complete the poem: 'Goat, must you stand here?/ Must you stand here still? / Is it that you will always stand here,/ Proof against faith, proof against innocence?'. Lexical repetition serves to reinforce, emphasize the main idea: putting the blame on another does not deprive the feeling of guilt, but only fortifies it. Twice repeated within the same line, 
'proof' and 'against' are intended to deny any existing faith or innocence. The effect is enhanced by the repetition of the verb 'must', which has a mean of 'total obligation'.

The lyrical hero addresses the image of an angel indirectly: 'Now if there is justice in the angel with the bright eyes, / He will say' Stop! 'And hand me a bough of cherry'.

The abstract concepts of 'justice', 'faith', 'innocence' appear as immeasurable epiphenomena, while 'goat' has both a physical embodiment (animal) and an abstract (incarnation of $\sin$ ). The noun 'justice' refers to the line where the bearded angel is mentioned, but the English sentence is conditional, expressing uncertainty, distrust, and therefore the very concept of justice is imprecise. The poem is expressed in the present and future tenses, so it's about the impossibility of redemption.

\section{Memory and its nature in the text}

The theme of collective memory is the subject of both lyrical poetry and prose. The 'Mara and Dann' dilogy touches on the idea of oblivion, the unreliability of human memory as such. The ecological catastrophe caused by mankind's actions has forced all living things to return to the cradle of life in Africa. The passage of time increasingly removes and erases from memory both the catastrophe itself and its causes. A desperate attempt of the ancestors to preserve the cultural and technical heritage of the past, to realize their own mistakes is futile. The human race is punished and remains in a kind of dream.

The theme of oblivion in a magical dream is also revalent in the last novel of the Nobel laureate, K. Ishiguro 'The Buried Giant' (2015). The work of K. Ishiguro, who immigrated with his family from Japan to Britain at an early age reveals common cross-cultural trends with D. Lessing.

However, D. Lessing in order to resolve the conflict between human permissiveness, the desire for power over the essence "turns" to the concept of eschatological myth, where the end of the known universe is a divine punishment for sins. In the mythological tradition, the world after a cataclysm (flood, earthquake, plague) plunges into chaos, which must be ordered. The "restart of time" happens. Thus, the repetition of the cosmogonic cycle arises. E. Meletinsky, a Soviet folklorist, suggests that such a concept of the "golden age" can be "directed" from chaos to space, and vice versa, endlessly repeating (Meletinsky, 2000).

$\mathrm{K}$. Ishiguro resorted to a magical solution to the conflict between alive enemies. There can be no peace between the British and the Saxons, who have just ended a bloody war. Memories of killed comrades are still alive. The mist that has engulfed Britain erases all contradictions. The fog appears as a kind of "branch of reconciliation", which allows combining the past, full of trouble, with the present, permeated with ghosts and lies. The authorial world of fragmented Britain, however, is more reminiscent of the afterlife - there is no place for wars, but the magical fog destroys what defines man from an animal - memory. Since memory cannot be selective, the murder of the dragon Querig, whose breath held back the onset of new troubles, marks the return of the memories of the people, and hence the guilt for the fratricide.

"Oblivion" in D. Lessing's novel differs from the state in which the characters of "The Buried Giant' bides, as it becomes a factor that makes it impossible to realize guilt. The generations that led to the apocalypse are long dead, their descendants have no memories of what happened, so they tend to repeat the mistakes of their predecessors. Time is moving further and further away from the point of catastrophe, erasing the boundaries of past and present.

There is a relevance for a guide who will pull humanity out of a long sleep and take on all the burden. There is a kind of transformation of collective sin into individual, its transfer from all mankind to a pair of scapegoats. Such figures are the main characters of the dilogy, Mara and 
Dann. The inevitable death to which a sister and brother are sent must wash away all the sins that mankind has committed.

\section{Conclusions}

Thus, the poetic work of D. Lessing, the author better known as a prose writer, reveals a common with prose thematization of important issues for all the author's heritage. The theme of creative nostalgia for the past, a desperate attempt to return to the world of childhood, a safe space is found in both the poetic works of D. Lessing and prose. Human memory becomes a tool for the study of the past, but after supplementing by the imagination, mixing with it turns out to be unreliable. Returning to the world of childhood in memories and rejection of adulthood, coming of age appears to be another common feature of poetry and prose. The lyrical heroine of the poem 'Fable', immersing herself in the depths of her memory, tries to protect herself from the hostile male world. The dimension of childhood, which exists only in distorted memories, emerges as a fortress, and an alien real-world outside, which always breaks through to the safe space of imagination.

D. Lessing's work reveals the presence of biblical motives, in particular the study of guilt and collective sin. The lyrical hero of the poem 'Oh Cherry trees you are too white for my heart' appeals to higher powers in search of justice and forgiveness, but is defeated. The angel, the mediator between God and men, who is supposed to "extend a saving hand" to bring order is transformed into a goat, in fact being equated with the devil. The lyrical hero is left alone in the desert with own feelings of guilt.

The author addresses the image of the scapegoat also in prose, "turning" the main characters of the dilogy 'Mara and Dann' into sacrificial animals. Their suffering and death must wash away all sins, and thus return humanity to the lost paradise.

\section{References}

The Nobel Prize in Literature 2007 [Electronic resource]. https:// www.nobelprize.org/nobel_ prizes/ literature/ laureates/2007/

Bakhtyn, M. M. (1979) Avtor y heroi v estetycheskoi deiatelnosty. Estetyka slovesnoho tvorchestva [Author and hero in aesthetic activity. Aesthetics of verbal creativity]. Moscow. [in Russian] Bentley, N.P (2015) Unanchored fragments of print: Lessing's Experiments with Drama and Poetry in the Late 1950s. Doris Lessing Studies, pp.19-26 (8)

Christine Murray. 'Fable' and 'Oh Cherry Trees You are Too White For My Heart' by Doris Lessing [Electronic resource]. Retrieved from: https:// poethead.wordpress.com/author/ poethead/

Lessing, D. (2009) Mara and Dann: An Adventure. HarperCollins e-books; Reprint edition Meletynskyi, E. M. (2000) Poetyka myfa [Poetics of myth]. Moscow: Vostochnaia lyteratura, RAN. [in Russian]

Miroshnychenko, L. Ya. (2012) Istoriia ta nostalhiia v romanakh Doris Lessinh. Visnyk Zaporizkoho natsionalnoho universytetu. Filolohichni nauky. [History and nostalgia in the novels of Doris Lessing. Bulletin of Zaporizhia National University. Philological Sciences] № 3, pp.173-180

Stein, $R$ (1975) The ritual of interpretation; The fine arts as literature in Ruskin, Rosseti, and Pater. Cambridge (Mass). London: Harvard University press.

The Bible. King James vesion. [Electronic resource]. Retrieved from: https://www.biblegateway.com/passage/? search $=$ Leviticus $\% 2016 \&$ version $=K J V$

Walder, D. (2008) Alone in a landscape: Lessing's African stories remembered. Journal of Commonwealth Literature, № 43(2) pp. 99-115.

Watkins, S (2010) Doris Lessing. Manchester: Manchester UP, Print. 